ORIENTAL JOURNAL OF CHEMISTRY

An International Open Access, Peer Reviewed Research Journal
ISSN: 0970-020 X

CODEN: OJCHEG

2021, Vol. 37, No.(3):

Pg. 673-678

www.orientjchem.org

\title{
Nutrients Analysis of Greenhouse Soil Nursed with the Organic Fertilizers
}

\author{
SYED KHALID MUSTAFA ${ }^{1 *}$ and MESHARI M.H. ALJOHANI ${ }^{2}$ \\ 1,2Department of Chemistry, Faculty of Science, University of Tabuk, Saudi Arabia. \\ ${ }^{*}$ Corresponding author E-mail: khalid.mustafa938@gmail.com
}

http://dx.doi.org/10.13005/ojc/370322

(Received: April 09, 2021; Accepted: May 19, 2021)

ABSTRACT

\begin{abstract}
The present work based on soil nutrients analysis of covered and uncovered fields nursed with organic fertilizer and cultivated with various crops. Collected the soil from three deep bottoms $(5 \mathrm{~cm}$, $15 \mathrm{~cm}$, and $30 \mathrm{~cm}$ ), mixed, and prepared five different samples. Calculated the $\mathrm{pH}$ value, electrical conductivity, and the percentage of nitrogen, phosphorus, potassium, the humus of the collected soil samples and documented all the parameters. The results showed that the soil has moderately high $\mathrm{pH}$ values (7.9 in the greenhouse and 7.5 in the uncovered area), the E.C of greenhouse $(4.1 \mathrm{dS} / \mathrm{m})$ is slightly lower than the uncovered area $(4.8 \mathrm{dS} / \mathrm{m})$, nitrogen $(6.3 \%$ than in the uncovered field $4.7 \%)$, relatively high concentration of phosphorus $(5.16 \mathrm{mg} / 100 \mathrm{~g}$ in the greenhouse uncovered field 4.67 $\mathrm{mg} / \mathrm{g})$, relatively high potassium values $(39.04 \mathrm{mg} / 100 \mathrm{~g}$ in the greenhouse and $36.30 \mathrm{mg} / \mathrm{g}$ in the uncovered area) and high values of humus (12.7\% in the greenhouse and $9.1 \%$ in the uncovered area). Concluded that the soil is saturated in the greenhouse with phosphorus and potassium, no need to further fertilizations in the forthcoming years and the greenhouse is better for crop cultivation.
\end{abstract}

Keywords: Organic Fertilizers, Greenhouse, PH, Quantitative analysis, Soil Fertility.

\section{INTRODUCTION}

According to the published reports, the cultivated greenhouse area was 275,000 hectares worldwide and 110 ha in India at the end of the $20^{\text {th }}$ century ${ }^{1}$. After two decades, as per the $31^{\text {st }}$ March 2020 report, the total area under the organic certification process in India is 3.67 million Hectare (registered under National Program for Organic Production 2019-20) $)^{2}$. As reported by the book FIBL \& IFOAM published in the Year 2018, India has $9^{\text {th }}$ position in terms of the World's Organic Agricultural land and $1^{\text {st }}$ in terms of total I number of producers. India is next to China, the second-largest producer of vegetables in the world. Horticulture production is increasing significantly in the country. There was a record production of $311.7 \mathrm{M} \mathrm{T}$ during 2017-18, which was $3.7 \%$ higher than the previous year and $10 \%$ higher than the past five years' average production. The vegetable contribution has remained the highest (59-61\%) in horticulture crop productions over the last five years. During 2017-18,

This is an Open Access article licensed under a Creative Commons license: Attribution 4.0 International (CC- BY). Published by Oriental Scientific Publishing Company @ 2018

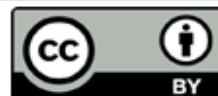


the area under vegetables was 10.3 million ha with a production of $\sim 180.0 \mathrm{MT}$ in India ${ }^{3}$. To commercialize the agricultural sector in India, plan to adapt Dutch farm production technology in the future. A group of Dutch companies is planning to initiate one of its projects in U. $\mathrm{P}^{4}$. Greenhouse crop cultivation is a different method of cultivation with various edges: improved aquatic-aerial regime, rapid surface heating, developed root system, decrease the crops diseases and getting good quality pests and harvest ${ }^{5-6}$, resulted in a better production of crops, whose rapid growth and development usually require superior quality nutrients with a proper combination of fertilization and irrigation ${ }^{7-8}$.

To improve soil fertility, peoples use solid animal manure, which has all the required biogenic elements. Despite that, some farmers use different quality and quantities of animal manure without knowing the soil condition and its requirement for supplementary nutrients. Hence without understanding the need, natural and artificial fertilizer generally leads to increased nutrients accumulation in the soil, resulting in soil fertility misbalance. Whereas for cultivation, the surplus use of nutrients in the soil is unusual. The crop production in protected areas (greenhouses and orangery) indicates lots of examples of surplus use of fertilizers. It has an advised effect on the harvest's quantity and quality ${ }^{9}$. Some workers reported that the concentration of nitrogen, phosphorus, potassium, and humus quantity needed more time for crop planting in greenhouses and maybe noted maximum after 5 to 10 years $^{10}$.

Therefore, the only suitable way for Greenhouse crop cultivation is to make an agrochemical analysis of the soil. The best indicator for the soil's fertility, i.e., shows the actual capacity and the level of available nutrients. Suggested the use and need of artificial and natural fertilizers on a scientific crop field, aiming to achieve more in quantity and high in quality of the harvest and protect the environment ${ }^{9}$. Thus the present study reported the consequences of such unplanned and uncontrolled fertilizers used to the greenhouse and bare field soil.

\section{MATERIAL AND METHODS}

\section{Field of examination}

The current study is based on an agrochemical analysis of the greenhouse and uncovered field (a private agricultural farmhouse at Shahabad (Rampur) U.P, India) soil constructed in 2015 and fertilized for several years solid animal manure. Initially, the agrochemical analysis didn't carry out of the soil. According to the "rule of thumb" principle, added solid animal (cow's) manure to the soil. The greenhouse ( $25 \mathrm{~m}$ by $4 \mathrm{~m}$ total area of 100 sq.m) covered with a nylon sheet, and an uncovered parcel with $25 \mathrm{~m}$ by $10 \mathrm{~m}$ (250 sq.m) was selected for the experiment. In vegetative season the greenhouse field cultivated the following crops, pepper (Capsicum annum), tomato (Solanum lycopersicum), celery (Apium graveolens), cucumber (Cucumis sativus), lettuce (Lactuca sativa), and onion (Allium cepa). Next to the greenhouse uncovered parcel is cultivated the following crops, pepper (Capsicum annum), tomato (Solanum lycopersicum), potato (Solanum tuberosum), carrot (Daucus carota), and bean (Phaseolus vulgaris). The crop cycle is exercised in the uncovered field, while in the greenhouse field in every vegetative season, the same crops are planted in the same place.

\section{EXPERIMENTAL}

Soil samples were collected for the agrochemical analysis during June 2019, after removing vegetation crops' harvest. The soil samples from covered and uncovered fields were collected from three deep bottoms $(5 \mathrm{~cm}, 15 \mathrm{~cm}$, and $30 \mathrm{~cm}$ ) and mixed. They prepared five different samples to study external factors influence and the difference between covered and uncovered soils ${ }^{11}$. The agrochemical analysis has been done, and the following parameters were calculated: Soil's $\mathrm{pH}$, electroconductivity, total nitrogen, available phosphorus, Potassium, and humus. Experiment works were carried out according to the standard laboratory methods ${ }^{12-20}$.

\section{RESULTS AND DISCUSSION}

The experimentally collected data from the evaluated parameters are mentioned in Index-1 and Index-2. The soil's analyzed data of the samples taken from the greenhouse (area under nylon foil) 
are mentioned in Table 1, although the uncovered area data are mentioned in Table 2 . The widely used indicators reported by different workers for assessing soil features are $\mathrm{pH}$ value, Soil electrical conductivity (E.C), and the volume of organic materials present in the soil. The present study included the estimation of phosphorus $(\mathrm{P})$, Potassium $(\mathrm{K})$ as well as nitrogen (N) [12-20]. Naturally, the collected data from the covered and uncovered field are quite different in their quantitative value. Because the covered areas have closed environments, so obviously, the temperature and humidity data values for the covered field are considerably higher compared to the uncovered field. Still, the electroconductivity of the soil of the uncovered area has a higher value than the covered field. Nutrients' (N, P, K, and PH values) distribution in the covered field's soil layers have a higher value than the uncovered fields because the covered area lacks natural rainwater. However, the obtained value from the covered and the uncovered fields indicated that the concentrations of nitrogen, phosphorus, Potassium and humus percentage have quantitatively decreased as going down inside.

Table 1: The calculated data of soil samples, collected from the greenhouse field

\begin{tabular}{cccccccc}
\hline $\begin{array}{c}\text { Distance } \\
\text { downward }(\mathrm{cm})\end{array}$ & $\begin{array}{c}\text { Moisture content } \\
(\%) \text { in percentage }\end{array}$ & $\begin{array}{c}\mathrm{pH} \text {-Value E.C. decisiemens } \\
\text { /meter }(\mathrm{dS} / \mathrm{m})\end{array}$ & $\begin{array}{c}\text { Nitrogen (\%) total } \\
\text { in percentage }\end{array}$ & $\begin{array}{c}\text { Humus (\%) } \\
\text { in percentage }\end{array}$ & $\begin{array}{c}\text { Available forms mg/100 g soil } \\
\mathrm{P}_{2} \mathrm{O}_{5}\end{array}$ \\
\hline 5 & 36 & 8.3 & 4.5 & 6.6 & 14.2 & 5.5 & 40.1 \\
$\mathrm{~K}_{2} \mathrm{O}$
\end{tabular}

Table 2: The calculated data of the soil samples, collected from the uncovered field

\begin{tabular}{|c|c|c|c|c|c|c|c|}
\hline \multirow{2}{*}{$\begin{array}{c}\text { Distance } \\
\text { downward }(\mathrm{cm})\end{array}$} & \multirow{2}{*}{$\begin{array}{l}\text { Moisture content } \\
(\%) \text { in percentage }\end{array}$} & \multirow[t]{2}{*}{$\mathrm{pH}$-Value } & \multirow{2}{*}{$\begin{array}{c}\text { EC decisiemens } \\
\text { /meter }(\mathrm{dS} / \mathrm{m})\end{array}$} & \multirow{2}{*}{$\begin{array}{l}\text { Nitrogen }(\%) \text { total } \\
\text { in percentage }\end{array}$} & \multirow{2}{*}{$\begin{array}{l}\text { Humus }(\%) \text { total } \\
\text { in percentage }\end{array}$} & \multicolumn{2}{|c|}{ Available forms $\mathrm{mg} / 100 \mathrm{~g}$ soil } \\
\hline & & & & & & $\mathrm{P}_{2} \mathrm{O} 5$ & $\mathrm{~K}_{2} \mathrm{O}$ \\
\hline 5 & 29 & 7.9 & 5.1 & 5.3 & 12.3 & 5.29 & 39.3 \\
\hline 15 & 38 & 7.5 & 4.9 & 4.7 & 8.1 & 4.61 & 35.7 \\
\hline 30 & 41 & 7.1 & 4.4 & 4.1 & 6.9 & 4.1 & 33.9 \\
\hline Average value & $36 \%$ & 7.5 & $4.8 \mathrm{dS} / \mathrm{m}$ & $4.70 \%$ & $9.10 \%$ & $4.67 \mathrm{mg} / 100 \mathrm{~g}$ & $36.30 \mathrm{mg} / \mathrm{g}$ \\
\hline
\end{tabular}

\section{Moisture content in the soil}

Moisture content in the soil is one of the essential healthy Soil parameters and should be up to $45 \%$. Dryness, as well as excess water, hindered the growth of plants. Therefore, for healthy plants, the appropriate moisture content in the soil is an essential factor. The calculated data shows that moisture is quantitatively more in the greenhouse field $45 \%$ than in the uncovered area $36 \%$. Its percentage increases as we move more inside to the earth. Usually, the soil moisture level is not in our control, depends on the climate. To some extent can be controlled in a greenhouse field [ 9 and references therein].

\section{Electro Conductivity value of the soil}

Soil electrical conductivity (E.C.) is an essential indicator of soil health to measure the total amount of salts present in soil or salinity of Soil measured in -decisiemens/meter $(\mathrm{dS} / \mathrm{m})$, its optimum value for a healthy soil should be 2.0 and $4.0 \mathrm{dSm}^{-1}$. It affects the emission of greenhouse gases, plant nutrient availability, and the activity of soil microorganisms. If the soil's available salts are in excess, it hampers the plant's growth, increasing water and land management. The obtained value of E.C. of greenhouse $(4.1 \mathrm{dS} / \mathrm{m})$ is slightly lower than the uncovered area $(4.8 \mathrm{ds} / \mathrm{m})$; it may be due to the natural composition of the soil, quality of irrigation water, as well as the period of sample collection ${ }^{15}$. Electrical conductivity levels indicate plant uptake nutrients and need to be identified and managed for better crops and land management.

\section{$\mathrm{pH}$ value of the soil}

The soil's $\mathrm{pH}$ value is one of the critical factors determining the mobility of ions and nutrient elements' availability to plants, which varies from 4 to 8.5 in different lands and conditions. The calculated value for the taken soil samples has average values of 7.9 for the greenhouse and 7.5 for the uncovered area, which is slightly basic, maybe due to animal manure in excess. It is not a healthy sign for crop production because it decreases the minerals' solubility in the soil and hinders the nutrients 
shortage. The good $\mathrm{pH}$ value for crops should be from 5.5 to 7.0, which shows some elements in larger quantities. Some nutrient elements are not available in adequate amounts for the healthy growth of crops and need to be using acid mineral fertilizers to decrease this parameter's value. For example, the availability of phosphorus is slightly decreasing in cases of higher $\mathrm{pH}$ of the soil. Simultaneously, it also reduces the availability of $\mathrm{Fe}, \mathrm{Mn}, \mathrm{Zn}, \mathrm{Cu}$, and $\mathrm{Ni}$, which harms crop growth ${ }^{15}$.

\section{Nitrogen percentage in the soil}

Nitrogen an essential nutrient of the soil, generally found in higher quantities at the upper or the humus layer of the soil, and its optimum amount should be 5 to 10 percent. The calculated data shows that the percentage of nitrogen is quantitatively more in the greenhouse field 6.3\%than in the uncovered area $4.7 \%$. Its quantity decreases as we move more inside of the earth. The presence of lower amounts of nitrogen in the soil than an optimum value needs to recommend the addition of nitrogenrich fertilizer. Organic fertilizers or animal excreta manure is also a good source of nitrogen for the soil; generally contain $5-18 \mathrm{~kg} \mathrm{~N} / \mathrm{t}$, in which half of it decomposed to give nitrogen fast. In the greenhouse, transformation occurs fast due to higher temperature, but in the alkaline and uncovered field's soil, a large percentage of nitrogen is lost in transformation processes $^{16,18}$.

\section{Humus percentage in the soil}

The soli has organic material, consisting of the dead parts of plant and animal, which gives carbon, nitrogen, sulfur, and many nutrients to the soil after its biological degradation increases its fertility and health. Its quality and quantity depend on the climate and animal manure used as fertilizer, soil and agriculture. Its optimum amount availability should be about 8 percent to 10 percent of the soil. The calculated data shows that the percentage of humus is quantitatively more in the greenhouse field, $12.7 \%$, than in the uncovered area, $9.1 \%$, and its quantity decrease as we move more inside to the earth. These refer to adequate presence regarding the humus contents ${ }^{13}$.

\section{Available phosphorus in the soil}

Phosphorus is another essential nutrients element for the soil, mainly available in Organic fertilizer, found in animal and green manure, compost, woodland cover, root remainders, dead microorganisms; its optimum amount availability should be $1.8-2.5 \mathrm{mg} / 100 \mathrm{~g}$. The calculated data shows that the phosphorus percentage is quantitatively more in the greenhouse field $(5.16 \mathrm{mg} / 100 \mathrm{~g})$ than in the uncovered area $(4.67 \mathrm{mg} / \mathrm{g})$. Its quantity decreases as we move more inside of the earth. The data shows phosphorus in high amounts, and it is recommended not to use phosphorus fertilizers in the following three successive years ${ }^{16,20}$.

\section{Available Potassium in the Soil}

Potassium's presence is another essential nutrient element for the soil, measured by using the Skene $\mathrm{K}$ or Colwell $\mathrm{K}$ tests. Potassium mainly available in Organic fertilizer, animal manure, compost, leaf, and root remainders; its optimum amount availability should be $18.1-30.0 \mathrm{mg} / 100 \mathrm{~g}$ (clay soil). The calculated data shows that the phosphorus percentage is quantitatively more in the greenhouse field $(39.04 \mathrm{mg} / 100 \mathrm{~g})$ than in the uncovered area ( $36.30 \mathrm{mg} / \mathrm{g}$ ). Its quantity decreases as we move more inside of the earth. The excess of Potassium available in the soil is unhealthy for crops because it hinders the soil's absorption of other essential nutrients. The data shows phosphorus in high quantity and it is recommended not to use phosphorus fertilizers in the following three successive years ${ }^{17}$.

\section{CONCLUSION}

The present study, based on the agrochemical analysis of the soil of the greenhouse with various crops and the uncovered field's soil, calculated the vital indicator for soil fertility and concentrations of nutrients, like $\mathrm{pH}$ value, electrical conductivity, quantitative analysis of nitrogen, phosphorus, Potassium, and humus. All parameters are documented in both covered and uncovered soil fields. The highest concentrations value of all parameters are calculated at the upper surface layer $(5 \mathrm{~cm})$, and the lowest at $30 \mathrm{~cm}$.

The average $\mathrm{pH}$ value reported as 7.9 in the greenhouse and 7.5 in the uncovered area, the obtained value of E.C of greenhouse $(4.1 \mathrm{dS} / \mathrm{m})$ is slightly lower than the uncovered area $(4.8 \mathrm{ds} / \mathrm{m})$, phosphorus concentrations $5.16 \mathrm{mg} / 100 \mathrm{~g}$ in the greenhouse, and $4.68 \mathrm{mg} / 100 \mathrm{~g}$ in the uncovered area, nitrogen $6.3 \%$ in the greenhouse and $4.7 \%$ in the uncovered area, Potassium $39.04 \mathrm{mg} / 100 \mathrm{~g}$ in the greenhouse and $36.33 \mathrm{mg} / \mathrm{g}$ in the uncovered 
area, soil humus as $12.7 \%$ in the greenhouse and $9.1 \%$ in the uncovered area.

Therefore, recommended that the soil is full of phosphorus and Potassium. Thus, the soil need not be used further additional fertilizer with organic manure in the following few years.

For better crop yield, soil health, and its management we need to improve the agricultural method and maintain the desired and optimum values of different soil parameters. The greenhouse technology has many advantages and better to maintain the desired and optimum values of various parameters of soil, need to educate the ordinary people.

\section{ACKNOWLEDGEMENT}

The authors like to acknowledge the support of the Department of Chemistry, Faculty of Science and University of Tabuk, Saudi Arabia. The authors also acknowledge and special thanks to Ana Korubin-Aleksoska and her team, who supported our analysis work.

\section{Conflicts of Interest}

The authors declare that there is no conflict of interest with someone else as well as somewhere else.

\section{REFERENCES}

1. Mishra, Both interaction surfaces within cohesin's hinge domain are essential for its stable chromosomal association. Current Biology., 2010, 20(4), 279-289, https://doi. org/10.1016/j.cub.2009.12.059.

2. Society, The Agricultural and Processed Food Products Export Development Authority (APEDA), Government of India updated, 2020. http://apeda.gov.in/apedawebsite/ about_apeda/About_apeda.htm.

3. International Greenhouse Vegetable Production-Statistics (2018 and 2019). https:// www.cuestaroble.com/statistics.html.

4. Grainmart News. 14 Nov. 2019 AnukritiAray: https://www.grainmart.in/news/author/ anukritiaray.

5. Lewandowski, A.; Zumwinkle, M.; Fish, A. Assessing the Soil System: A Review of Soil Quality Literature; Minnesota Department of Agriculture, Energy and Sustainable Agriculture Program: St. Paul, MN, USA, 1999.

6. Agency for promotion of agricultural development, Bitola, Republic of Macedonia, (ISO 9001: 2015), https://agencija.gov.mk

7. Doran, J.W.; Parkin, T.B. Defining and assessing soil quality. In Defining Soil Quality for a Sustainable Environment; SSSA Special Publication 35; Doran, J.W., Coleman, D.C., Bezdicek, D.F., Stewart, B.A., Eds.; Soil Science Society of America: Madison, WI,
USA, 1994, 1-21.

8. Qiang Liu.; Hongwei Xu.; Xingmin Mu.; Guangju Zhao.; Peng Gao.; and Wenyi Sun, Effects of different fertilization regimes on crop yield and soil water Use efficiency of millet and Soybean, Sustainability (MDPI), 2020, 12(4125), 1-13.

9. Budoin W.; Nano-Womdim. R.; Lutaladio, N. \& Hodder . A, Good Agricultural Practices for greenhouse vegetable crops.Food and Agriculture Organization of the United Nations Plant Production and Protection Division., 2013.

10. Li. J.; Xu. Y \& Liu H. G Variations of soil quality from continuously planting greenhouses in North China. Int J Agric \& Biol Eng., 2019, 12(1), 139-145.

11. Trajkova. F, \& Zlatkovski. V. Guide for taking soil samples from agricultural areas. University "Goce Delchev"-Stip, Faculty of Agriculture., 2017.

12. Bunemann. E.K. \& Soil quality-A critical review: Soil Biology and Biochemistry., 2018, 120, 105-125.

13. Liang, Y.; Lin. X.; Yamada, S.; Inoue, M.; Inosako, K., Soil degradation and prevention in greenhouse production.2010 International Conference on Combating Land Degradation in Agricultural Areas (ICCLD'10) Zi'An City, PR China. 11-15 October 2010. 
14. USDA Natural Resources Conservation Service. Soil Quality Indicators.(2011). https://www.nrcs.usda.gov/wps/portal/ $\mathrm{nrcs} / \mathrm{detail} / \mathrm{soils} / \mathrm{health} / \mathrm{assessment/?}$ cid=stelprdb1237387.

15. Smith, J. L. and J.W. Doran. Measurement and use of $\mathrm{pH}$ and electrical conductivity for soil quality analysis.In J.W. Doran and A.J. Jones (ed.) Methods for assessing soil quality. Soil Science Society of America Spec. Publ. 49.SSSA, Madison, WI. 1996, 169-185.

16. Baxter N.; Williamson, J., Know Your Soils: Part 1 Introduction to Soils, Department of Natural Resources and Environment, Victorian resources online., 2001.

17. Skene JKM., Soil analysis as an aid to diagnosing deficiencies of phosphorus and Potassium. In Proceedings Australian Plant Nutrition Conference'. Melbourne. (CSIRO: Melbourne)., 1956, 146-153.

18. Ladha, J.K.; Pathak, H.; Krupnik, T.J.; Six, J.; van Kessel, C. Efficiency of fertilizer nitrogen in cereal production: Retrospects and prospects. Adv. Agron., 2005, 87, 85-156.

19. Evans, C. E. "Soil test calibration". In Soil testing: Sampling, correlation, calibration and interpretation, Edited by: Brown, J. R. 23-29. Madison, Wisconsin: SSSA., 1987.

20. Zhang, Y.; Peng, M.;Wang, J.; Gao, Q.; Cao, M.; Yang, Z. Corn yield response to phosphorus fertilization in northeastern China. Agron. J., 2015, 107, 1135-1140. 